\title{
Herbal medicines from ginkgo leaf extract in the treatment of mild dementia
}

\author{
Silvana Petrović ${ }^{*}$ Ljuboš Ušjak \\ University of Belgrade - Faculty of Pharmacy, Department of Pharmacognosy, \\ Vojvode Stepe 450, 11221 Belgrade, Serbia \\ Corresponding author: Silvana Petrović, \\ e-mail: silvana.petrovic@pharmacy.bg.ac.rs
}

\begin{abstract}
Summary
According to current EU monograph of the Committee on Herbal Medicinal Products of European Medicines Agency (EMA/HMPC) for ginkgo leaf, Ginkgonis folium (Ginkgo biloba, Ginkgoaceae), herbal medicines prepared from refined and quantified dry extract of ginkgo leaf are used for the improvement of (age-associated) cognitive impairment and of quality of life in mild dementia. It was demonstrated in clinical trials that long-term use of the extract is effective mainly in patients more than 50 years old. The precise mode of action is not known. According to Ph. Eur., the extract should contain $22.0-27.0 \%$ of flavonoids, $2.8-3.4 \%$ of ginkgolides A, B and $\mathrm{C}$, and $2.6-3.2 \%$ of bilobalide, which are active constituents, and maximum $5 \mathrm{ppm}$ of ginkgolic acids, which are potential allergens. These herbal medicines are characterized by corresponding posology, duration of use, contraindications, special warnings, and precautions for use, interactions and possible undesirable reactions.
\end{abstract}

Keywords: Ginkgo biloba; leaf extract; mild dementia; herbal medicines; efficacy and safety 


\section{Introduction}

The number of people suffering from dementia is rising rapidly. It affected 47 million people in 2015 and the predictions are that this number will increase to 75 million in 2030 and 132 million by 2050 (1). Up until the late 1960s, it was thought that senile dementia is of vascular etiology (2). Today it is known that vascular dementia (VaD) is the second most abundant type of dementia (15-25\%), after dementia in Alzheimer's disease (AD), which is the most common one (60-75\%) $(2,3)$. Although pure $\mathrm{VaD}$ and $\mathrm{AD}$ exist, in neuropathology examinations it is often found that these two pathologies are mixed (3).

Among herbal medicines, those prepared from the appropriate dried, purified extract of ginkgo leaf are widely used in dementia treatment since the 1990s (3). In the year 2015 the Committee on Herbal Medicinal Products of European Medicines Agency (EMA/HMPC) approved well-established use (WEU) of this ginkgo leaf extract in therapeutic area circulatory disorders (4), for improvement of (age-associated) cognitive impairment and of quality of life in mild dementia (5).

\section{The ginkgo tree}

The ginkgo tree, Ginkgo biloba L. (Ginkgoaceae), often referred to as ,the living fossil", is Tertiary relict and the sole survivor of the gymnosperm class Ginkgoatae, which representatives were widely distributed on Earth during Mesozoic (6-8). The term biloba is related to bilobed shape of the leaves (9). This tall, deciduous tree grows in wild in China, Japan, and Korea, but only a few localities in China represent its natural refugia $(6,8)$. Ginkgo is also cultivated, both for use in pharmaceutical industry and in parks as ornamental tree. It is very resistant to plant diseases, as well as air pollution, and thus it is suitable for cultivation in urban areas $(6,10)$.

The ginkgo tree is a dioecious plant; female individuals produce seeds (often wrongly called fruits or nuts) $(6,11)$. In Chinese traditional medicine, ginkgo seeds have a long history of use as a tonic and against asthma, chronic bronchitis, tuberculosis, some urinary and gynecological disorders, etc. They are also consumed as food (but are potentially toxic in larger amounts). On the other hand, only very few historical records (dating from the 15th and 16th century) on the traditional use of ginkgo leaves in China exist (dermally against freckles, and internally to treat dysentery and diarrhea) $(10,12,13)$. The leaves have been introduced in the late 1970s into Chinese pharmacopoeias, for the treatment of cardiovascular and pulmonary diseases $(12,13)$. 


\section{Use of ginkgo leaf extract in mild dementia}

\section{Pharmaceutical quality}

For use in the pharmaceutical industry, ginkgo leaf is mainly collected from plantations in China, France, and the USA; it is also cultivated in Australia, Korea, Japan and New Zealand (14). Cultivated ginkgo trees are pruned into bush forms, and the leaves are harvested with appropriate machines (13).

Pharmaceutical quality of the herbal drug Ginkgonis folium and the corresponding extract is defined in European Pharmacopoeia ( $\mathrm{Ph}$. Eur.) monographs. Ginkgonis folium ${ }^{1}$ is official in Ph. Eur. starting from 2002 (edition 4.0) and represents whole or fragmented, dried leaf of Ginkgo biloba. It should contain not less than $0.5 \%$ of flavonoids, expressed as flavone glycosides (determined by HPLC method). Ginkgo dry extract, refined and quantified, Ginkgonis extractum siccum raffinatum et quantificatum, is official in $\mathrm{Ph}$. Eur. starting from 2008 (edition 6.1), and is produced from the herbal drug by an appropriate procedure using organic solvents and their mixtures with water, physical separation steps, as well as other suitable processes. The extract should contain $22.0-27.0 \%$ of flavonoids, expressed as flavone glycosides, $2.6-3.2 \%$ of bilobalide, $2.8-3.4 \%$ of ginkgolides A, B, and $\mathrm{C}$, and maximum $5 \mathrm{ppm}$ ginkgolic acids (constituents are determined by HPLC method) (16).

According to EMA/HMPC EU monograph on ginkgo leaf, herbal medicinal products with well-established use (WEU HMPs) are prepared from the dry extract of the ginkgo leaf (DER 35-67:1; acetone 60\%, w/w), and this extract should be in accordance with $\mathrm{Ph}$. Eur. monograph Ginkgonis extractum siccum raffinatum et quantificatum (5). The composition of this extract, in general, corresponds to patented, so-called special extracts EGb 761 and LI $1370^{2}$ (18). Extract EGb 761 was patented by German pharmaceutical company Dr. Willmar Schwabe, in cooperation with French pharmaceutical company Beaufour-IPSEN, and LI 1370 by another German pharmaceutical company Lichtwer Pharma $(13,19)$. Publication of EMA/HMPC EU monograph has made it possible to market herbal medicines not only from EGb 761 (most commonly) and LI 1370 but also from other extracts that meet the quality requirements.

Multiple purification of the extract aims to achieve high content of active principles and to decrease the content or remove undesirable components (13). Active principles include flavonoids and terpene lactones. Among flavonoids, the most common are glycosides of kaempferol, quercetin, and isorhamnetin, i.e. their mono-, bi- and triosides

1 In the literature, Latin name Ginkgo folium is also found; however this term is not appropriate because in Latin name of herbal drug, the name of plant genus (in this case Ginkgo) must be in genitive (i.e. Ginkgonis) (15).

2 According to previous regulations, these extracts were referred to as standardized (lat. normatum). However, according to current Ph. Eur. and EMA classification, they represent quantified extracts (lat. quantificatum) $(16,17)$. 
(glucose, rhamnose, and glucorhamnose are usual sugar units), as well as esters of biosides with $p$-coumaric acid. The extract also contains smaller amounts of glycosides of apigenin and luteolin. Terpene lactones comprise diterpene trilactones: ginkgolides A, $\mathrm{B}, \mathrm{C}, \mathrm{J}$ and $\mathrm{M}$, and sesquiterpene trilactone bilobalide $(13,20)$.

Undesirable components include compounds with large molecular mass: tannins (polymeric proanthocyanidins, PPC), polysaccharides and proteins, and compounds that are slightly soluble in water: biflavones, e.g. amentoflavone, bilobetin, ginkgetin, as well as ginkgolic acids. Ginkgolic acids represent 2-hydroxy-6-alkylbenzoic acids with different side alkyl chains. They are potential allergens, and because of that their maximum content is limited to $5 \mathrm{ppm}(13,20)$.

Besides, ginkgotoxin (4'-O-methylpyridoxine) also potentially raises safety concerns on the use of ginkgo leaf extract. It acts as an antivitamin of vitamin B6 (11); deficiency of vitamin B6 could trigger seizures in some patients with epilepsy (21). Because of this, corresponding precautions regarding the use of ginkgo leaf extract in patients with epilepsy exist (5). Ginkgotoxin is partially removed during the manufacturing process patented by Dr. Willmar Schwabe, i.e. EGb 761 contains less than 200 ppm of this constituent (13).

\section{Clinical efficacy}

More than 60 various clinical trials testing ginkgo leaf extracts in patients diagnosed with some type of dementia or similar condition (first trials included patients diagnosed with cerebrovascular insufficiency) have been conducted since the 1970s $(3,13,22)$.

EMA/HMPC assessed 19 randomized, controlled and double-blind clinical trials; in 15 of them ginkgo leaf extract EGb 761 was tested, and nine of these (one lasted for a year, eight for six months) involved patients with mild to moderate dementia, including patients with Alzheimer disease (AD), vascular dementia (VaD) and/or mixed form of dementia (patients were more than 45 years old in one study, and more than 50 years old in other studies) (23).

In six of nine of these studies, conclusions were positive [Herrschaft et al. (24), Ihl et al. (25-27), Napryeyenko et al. (28,29), Kanowski et al. (30,31), Le Bars et al. (32) and Yancheva et al. (33)]. In trials on patients with different types of dementia, mainly general conclusions (regardless of dementia type) were drawn, while in three more recent studies [Herrschaft et al. (24), Ihl et al. (25-27) and Napryeyenko et al. $(28,29)$ ], the effects of the extract were assessed in every type of dementia separately, and in all three cases conclusions were positive. Besides the effect on cognitive performance, in studies of Herrschaft et al. (24) and Ihl et al. (25-27), improvement of patients' quality of life is also highlighted. Eight of nine of these trials were placebo-controlled. Only in one study (on patients with $\mathrm{AD}$ ), a drug (donepezil) was used as a control; the authors hypothesized that there was ,no significant difference in the efficiency between ginkgo leaf extract and 
donepezil", and that combination therapy was superior compared to monotherapy, with fewer side effects. However, the main drawback of this study is the fact that it was conducted on a small number of patients with AD [Yancheva et al. (33)]. Despite having limited and transient efficacy, acetylcholinesterase (AChE) inhibitors (tacrine, donepezil, rivastigmine, and galantamine) and N-methyl-D-aspartic acid (NMDA) receptor antagonist memantine are the only drugs approved for treating AD (34), and further, welldesigned studies comparing the efficacy of these drugs with ginkgo leaf extract, as well as those investigating efficacy of their combined therapy in AD are necessary.

In two of nine above-mentioned studies, the conclusions were negative [Van Dongen et al. (35) and McCarney et al. (36)]. However, in one of them, the lower daily dose of the extract $(120 \mathrm{mg}$ ) was administered (36). In the remaining study [Schneider et al. (37)], the conclusion was not drawn.

EMA/HMPC (23) also evaluated five meta-analyses (involving 819-4423 patients), two of which (on 2138 and 2372 patients) included only clinical trials testing EGb 761 extract (all among nine above-mentioned studies) and both led to positive conclusions $(38,39)$. EMA/HMPC also assessed negative Cochrane meta-analysis (22). According to this meta-analysis, ,the evidence that ginkgo leaf extract has predictable and clinically significant benefit for people with dementia or cognitive impairment is inconsistent and unreliable", due to unsatisfactory design of the most of the assessed trials (different extracts, doses, duration of treatment, a small number of patients, etc.). Cochrane metaanalysis comprised much larger number (i.e. 36) of clinical trials, compared to two discussed above (nine and six), thus it was less restrictive, and also recent, affirmative studies [Herrschaft et al. (24) and Ihl et al. (25-27)] were not available to the authors.

Based on all these facts, EMA/HMPC concluded that the extract in a daily dose of $240 \mathrm{mg}$ fulfills criteria (i.e. there is enough clinical evidence) for well-established use herbal medicinal product (WEU HMP); long term administration of the extract resulted in improvement of cognitive performance in older patients, especially in those of 50 years and above (the most relevant clinical trials were performed in subjects aged 50 and older) (23).

This EMA/HMPC indication differs from those given in older monographs on ginkgo leaf, earlier published by Commission E of German Federal Institute for Drugs and Medical Devices (40), World Health Organization, WHO (41) and European Scientific Cooperative On Phytotherapy, ESCOP (42). While in older monographs types of dementia are stated (i.e. symptomatic treatment of dementia syndromes, including primary degenerative dementia, vascular dementia, and mixed forms of both), in EMA/HMPC EU monograph this is no longer the case.

Among 15 previously mentioned clinical trials dealing with EGb 761 (assessed by EMA/HMPC), in two large, long-term, multicenter, randomized, double-blind and placebo-controlled studies [DeKosky et al. (43), lasted for 6.1 years on 3069 patients 
more than 75 years old, and Vellas et al. (44), lasted for 5 years on 2854 patients more than 70 years old], the potential of the extract to prevent dementia was investigated. In both studies, it was concluded that the extract was ,not effective in reducing either the overall incidence rate of dementia or AD incidence in elderly individuals with normal cognition or those with mild cognitive impairment (MCI)" (23). The recommendation in National guideline for AD of the Republic of Serbia (45) is based on the results of these two trials, as well as on the additional analysis of the results of DeKosky et al. (43), performed by Snitz et al. (46), in which it was concluded that the use of the extract „did not result in less cognitive decline in adults (aged 75 and older) with normal cognition or with MCI" (45).

Similarly to our National guideline for $\mathrm{AD}$, according to German guideline for dementia, EGb 761 is not recommended for the prevention of dementia (47). In both German guideline for dementia and German guideline for vascular dementia, it is additionally stated, based on newer evidence on clinical efficacy [Herrschaft et al. (24) and Ihl et al. $(26,27)]$, that EGb 761 in a daily dose of $240 \mathrm{mg}$ can be considered in dementia treatment $(47,48)$.

In a recent meta-analysis, performed by Savaskan et al. (49) (after the publication of EMA/HMPC Assessment report and EU Monograph on ginkgo leaf), the effect of EGb 761 on neuropsychiatric symptoms in patients with dementia was evaluated. This metaanalysis comprised four randomized, placebo-controlled, double-blind clinical trials involving the total of 1628 patients [Herrschaft et al. (24), Ihl et al. (26), Napryeyenko et al. (28) and Nikolova et al. (50)] and drawn conclusion that the extract improves behavioral and psychological symptoms (except psychotic-like features) in patients suffering from $\mathrm{AD}$ and from $\mathrm{VaD}$ when it was given for 22-24 weeks in a daily dose of $240 \mathrm{mg}$.

It is important to note that other indications included in older monographs on ginkgo leaf (Commission E, WHO, ESCOP), i.e. neurosensory disorders: vertigo and tinnitus, as well as peripheral arterial occlusive disease (PAOD) in stage II according to Fontaine (intermittent claudication) (40-42), were not listed in EMA/HMPC EU monograph. Namely, subsequent analysis of clinical trials on patients with vertigo, tinnitus, and PAOD, as well as evaluation of newer trials on patients with tinnitus and PAOD showed that there is not enough clinical evidence on efficacy for these indications (23). However, in a recent meta-analysis (51) of five clinical trials (on a total of 2111 subjects) [Herrschaft et al. (24), Ihl et al. (26), Napryeyenko et al. (28), Schneider et al. (37) and Nikolova et al. (50)], on patients with dementia suffering at the same time from vertigo and tinnitus, it is concluded that EGb 761 in a daily dose of $240 \mathrm{mg}$ alleviates these neurosensory symptoms. 


\section{Pharmacological effects}

The exact mode of action of ginkgo leaf extract in mild dementia is not known. Increased vigilance (measured in EEG test) in geriatric patients (60 subjects, 57-77 years old) with age-related mental deterioration was observed (52).

Most pharmacological studies demonstrated its effects on cerebral (as well as peripheral) circulation. Human pharmacological data show a decrease in blood viscosity and improvement of cerebral perfusion in specific areas in healthy male volunteers (48 patients, 60-70 years old) (53), reduction in platelet aggregation (ex vivo) (54) and vasodilation of forearm blood vessels causing increased regional blood flow in healthy subjects (16 patients, 21-47 years old) (55). A study in mice demonstrated that the extract and its flavonoid-free fraction prolonged the survival time under lethal hypoxia (56). In another study in mice, bilobalide and ginkgolides A and B significantly reduced the infarct size after occlusion of the middle cerebral artery (57). Accordingly, in vitro and in vivo (in rats) experiments showed that the extract and bilobalide improved mitochondrial function, attenuating the hypoxia-induced ATP decrease $(13,58)$. The protective effect of the extract and bilobalide on brain edema in rats was also demonstrated (13). Also, the extract protected tissues (both brain and myocardium) from ischemia/reperfusion damages (showed in vivo in rats and in vitro) (59). In a search for mechanisms underlying these pharmacological effects, in vitro studies using rabbit platelets $(60,61)$ and human platelets (62), showed that ginkgolides A, B, and C inhibit platelet-activating factor (PAF). Furthermore, in vitro experiments on human endothelial cells, isolated rat aortic rings, as well as in vivo experiments in rats demonstrated that the extract promotes endothelial NO release $(13,63)$.

Other studies showed antioxidant and anti-inflammatory activities of the extract and its constituents. Radical scavenging potential of ginkgo flavonoids, as well as the ability of the extract to increase levels of antioxidant enzymes (such as superoxide dismutase, glutathione peroxidase, and catalase), were demonstrated in vivo and/or in vitro (64). An in vitro study showed that ginkgolides A and B inhibited TNF- $\alpha$ and IL-1 (65); inhibition of PAF, which also has pro-inflammatory properties, contributes to anti-inflammatory activity (64).

Antioxidant and anti-inflammatory activity and protective effects in hypoxia contribute to the neuroprotective potential of ginkgo leaf extract. Additionally, other effects that can contribute to neuroprotection were also shown: anti-apoptotic effect (in vitro for the extract, ginkgolides $\mathrm{B}$ and $\mathrm{J}$, bilobalide and quercetin), protective effects against amyloidogenesis (for the extract in vitro and in vivo in mice) and amyloid- $\beta$ aggregation (in vitro for the extract, ginkgolide $\mathrm{J}$, bilobalide and flavonoid fraction), modulation of phosphorylation of tau protein (for the extract in vivo in rat hippocampus), etc. (64). 
Effects on neurotransmission were also observed in some in vitro and in vivo studies (13). Chronic oral treatment with the extract led to the increase of muscarinic receptors number and cholinergic transmission in the hippocampus of aged rats (66). The extract and its two specific quercetin and kaempferol biosides esters with $p$-coumaric acid (together they comprise about $4.5 \%$ of EGb 761) increased dopamine and acetylcholine levels in the rat medial prefrontal cortex after oral administration (the effect was not observed with aglycone isorhamnetin) (67).

\section{Well-established use herbal medicinal products (WEU HMPs) from ginkgo leaf extract in mild dementia}

\section{Posology and duration of use}

WEU HMPs from the refined and quantified dry extract of ginkgo leaf are prepared in liquid or solid dosage forms for oral use. In adults and elderly, a single dose is 120-240 $\mathrm{mg}$ and a daily dose is $240 \mathrm{mg}$. For children and adolescents, no relevant indication exists. Treatment should last for at least eight weeks, and after three months, if there is no improvement of symptoms or if they intensify, a doctor should evaluate the justifiability of continuation of the treatment (5).

\section{Contraindications, special warnings, and precautions for use}

WEU HMPs from ginkgo leaf extract are contraindicated in the case of hypersensitivity to the active substance or pregnancy.

They can be used only after consultation with a doctor in patients with a pathologically increased bleeding tendency (hemorrhagic diathesis) and those taking anticoagulants and antiplatelet drugs. As a precaution, these HMPs should be discontinued three to four days before surgery, since they might increase susceptibility to bleeding (5). These precautions are based on the fact that ginkgo leaf extract affects platelet aggregation $(23,54)$.

In patients suffering from epilepsy, further seizures induced by the use of ginkgo leaf extract cannot be excluded (5). This precaution is introduced because the recurrence of well-controlled epilepsy after administration of ginkgo leaf extract was reported by two elderly patients. However, it was not specified exactly which ginkgo leaf extracts were taken in these cases (68). It is already mentioned that convulsions could be attributed to ginkgotoxin and that during the manufacturing process of EGb 761, the content of ginkgotoxin is lowered to maximally $200 \mathrm{ppm}$, which means that administration of a daily dose of the extract $(240 \mathrm{mg}$ ) results in the intake of approximately $48 \mu \mathrm{g}$ of ginkgotoxin. On the other hand, the seeds contain a much higher quantity of ginkgotoxin, i.e. up to 85 $\mu \mathrm{g} / \mathrm{raw}$ seed. Thus, the risk of convulsions is much higher after the consumption of seeds. For example, in children convulsions were observed after consuming 15-60 raw seeds $(11,13)$. 


\section{Interactions}

Ginkgo leaf extract may potentiate the effect of anticoagulants (e.g. warfarin and dabigatran) or antiplatelet drugs (e.g. acetylsalicylic acid and clopidogrel) (5) because ginkgolides inhibit PAF (60-62). In addition, possible potentiation of the effect of dabigatran (formulated as prodrug dabigatran etexilate, which is a substrate for intestinal P-glycoprotein) (69) is suggested based on two studies on 10 and 12 healthy male volunteers, which indicated that ginkgo leaf extract may inhibit intestinal P-glycoprotein $(70,71)$.

In one study, the interaction of ginkgo leaf extract with nifedipine was investigated in eight healthy volunteers, and in two of them, maximum serum concentrations of nifedipine were doubled. These two subjects experienced dizziness and increased severity of hot flushes $(5,23,72)$.

The use of ginkgo leaf extract with efavirenz is not recommended because serum levels of efavirenz may be decreased due to CYP3A4 induction $(5,23,73)$.

\section{Pregnancy and lactation}

The use of ginkgo leaf extract is contraindicated in pregnancy, mainly because it may increase the tendency for bleeding. There are no sufficient animal studies regarding reproductive toxicity, and published data are contradictory (5). For example, a study in mice showed that EGb 761 affected fertility and reproductive performance, caused vaginal bleeding, and reduced fetal viability $(23,74)$, while a study in rats and rabbits did not show similar effects $(23,75)$.

The effects of some ginkgo leaf extract components were also tested. It was shown that ginkgolide $\mathrm{B}$ reduced the rate of maturation of oocytes, fertilization, and fetal development in vitro and in vivo in mice $(23,76)$. Both ginkgolides $\mathrm{A}$ and $\mathrm{B}$, in vitro led to apoptosis, decreased cell numbers, retarded early postimplantation development, and increased early-stage death of mouse blastocysts $(23,77)$. High toxic potential on chick embryos was found for fractions rich in ginkgolic acids $(23,78)$, but their content in ginkgo leaf purified extract is limited to a maximum 5 ppm (16).

Because of insufficient data, it is not recommended to use the extract during lactation (5).

\section{Undesirable effects}

In several clinical trials and meta-analyses, it is concluded that the use of ginkgo leaf extract is safe $(3,22,79-81)$. Among spontaneously reported undesirable effects, headache is reported as very common, and dizziness and gastrointestinal disorders (such as diarrhoea, abdominal pain, nausea, and vomiting) as common. Hypersensitivity reactions, including allergic skin reactions and other skin and subcutaneous tissue disorders of unknown frequency may also occur (5). A few cases of bleeding (eye, nose, 
cerebral and gastrointestinal hemorrhage of unknown frequency) were reported after longtime treatment, but details on ginkgo leaf extracts taken are not specified. However, in clinical studies with EGb 761, such adverse effects have not been reported $(3,22,23,79$ 81). Moreover, based on concentrations of ginkgolides $\mathrm{A}, \mathrm{B}$ and $\mathrm{C}$ that inhibited PAF in vitro and their serum levels after oral intake of the extract in a daily dose, Koch (62) expressed his doubts that ginkgolides could be responsible for potential hemorrhage in patients taking EGb 761 (62).

EMA/HMPC concluded that overall, ginkgo leaf preparations have a reasonable safety profile (23).

\section{Traditional herbal medicinal products (THMPs) from dried ginkgo leaf in peripheral circulatory disorders}

As it is already stated, for WEU HMPs from ginkgo leaf extract, EMA/HMPC did not approve an indication peripheral arterial occlusive disease (23). On the other hand, EMA/HMPC approved traditional use of dried powdered leaf of ginkgo for the relief of the sensation of cold hands and feet, as well as the heaviness of legs associated with minor circulatory disorders, after serious conditions have been excluded by a doctor (5). The sensation of cold hands and feet and heaviness of legs refer to disorders of peripheral arterial and venous circulation, respectively $(82,83)$.

THMPs are prepared in solid dosage forms for oral use. For adults and elderly, a single dose is $250-360 \mathrm{mg}$, and a daily dose is $750 \mathrm{mg}$ of the dried powdered ginkgo leaf. In the absence of adequate data, for children and adolescents under 18 years the use of these THMPs is not recommended. In the case that the symptoms exist for more than two weeks, the advice of a doctor or a qualified health care practitioner should be sought. The use is contraindicated in the case of hypersensitivity to the active substance. THMPs may enhance the effects of anticoagulants. Because of insufficient data, it is not recommended to use these THMPs during lactation. Regarding undesirable effects, gastrointestinal disorders, headaches, and allergic reactions of unknown frequency were reported (5).

Corresponding differences in contraindications, special warnings, precautions for use and undesirable effects of THMPs compared to WEU HMPs can be explained by the fact that WEU HMPs are prepared from highly concentrated ginkgo leaf extract, containing much higher amounts of ingredients.

\section{Conclusion}

According to current EU monograph of EMA/HMPC for ginkgo leaf, wellestablished use herbal medicinal products (WEU HMPs) prepared from refined and quantified dry extract of ginkgo leaf, Ginkgonis extractum siccum raffinatum et quantificatum, are used for the improvement of cognitive impairment associated with age and of quality of life in mild dementia, in a daily dose of $240 \mathrm{mg}$, during for at least eight 
weeks. EMA/HMPC defined the indication and posology based on the evaluation of corresponding recent clinical studies and meta-analyses, and it should be noted that they differ significantly from those reported in older monographs which refer to efficacy and safety of ginkgo leaf extract.

It should be noted that WEU HMPs from ginkgo leaf extract are among the most accessible HMPs in Europe. For example, in the different countries of the European Union, by 31. December 2016, there was a total of 111 approved marketing authorizations (MA) for WEU HMPs from ginkgo leaf extract (this is the second largest number of approved MA for any of WEU HMPs) (84). In the Republic of Serbia currently, four WEU HMPs from ginkgo leaf extract are authorized (all four are in accordance with the EMA/HMPC EU monograph) (85). Finally, considering the no prescription required dispensing regimen of these WEU HMPs, the role of pharmacists in their rational use is emphasized.

\section{References}

1. World Health Organization (WHO). Global action plan on the public health response to dementia 2017-2025. Geneva: 2017.

2. O'Brien JT, Thomas A. Vascular dementia. Lancet. 2015;386:1698-706.

3. Yuan Q, Wang CW, Shi J, Lin ZX. Effects of Ginkgo biloba on dementia: An overview of systematic reviews. J Ethnopharmacol. 2017;195:1-9.

4. European Medicines Agency (Table of herbal medicines) [Internet] [cited 2020 February 10]. Available from: https://www.ema.europa.eu/en/medicines/download-medicine-data\#therbalmedicines-section

5. European Medicines Agency. EMA/HMPC/321097/2012. European Union herbal monograph on Ginkgo biloba L., folium. London: 28 January 2015.

6. Del Tredici P. The evolution, ecology, and cultivation of Ginkgo biloba. van Beek TA, editor. London: CRC Press; 2000; pp. 25-42.

7. Hohmann N, Wolf EM, Rigault P, Zhou W, Kiefer M, Zhao Y, et al. Ginkgo biloba's footprint of dynamic Pleistocene history dates back only 390,000 years ago. BMC Genomics. 2018;19(1):299.

8. Zhao YP, Fan G, Yin PP, Sun S, Li N, Hong X, et al. Resequencing 545 ginkgo genomes across the world reveals the evolutionary history of the living fossil. Nat Commun. 2019;10(1):1-10.

9. Isah T. Rethinking Ginkgo biloba L.: Medicinal uses and conservation. Phog Rev. 2015;9(18):140-8.

10. Mahady GB. Ginkgo biloba for the prevention and treatment of cardiovascular disease: a review of the literature. J Cardiovasc Nurs. 2002;16(4):21-32.

11. Leistner E, Drewke C. Ginkgo biloba and ginkgotoxin. J Nat Prod. 2010;73(1):86-92.

12. DeFeudis FV. A brief history of EGb 761 and its therapeutic uses. Pharmacopsychiatry. 2003;36 Suppl 1:S2-S7. 
13. Lang F, Hoerr R, Noeldner M, Koch E. Ginkgo biloba extract EGb 761®: From an ancient Asian plant to a modern European herbal medicinal product. Wagner H, Ulrich-Merzenich G, editors. Vienna: Springer; 2013; pp. 431-70.

14. Gafner S. Adulteration of Ginkgo biloba leaf extract. Botanical Adulterants Bulletin [Internet]. American Botanical Council (ABC), the American Herbal Pharmacopoeia (AHP), and the University of Mississippi's National Center for Natural Products Research (NCNPR): Botanical Adulterants Prevention Program; 2018 [cited 2020 Feb 10]. Available from: http://cms.herbalgram.org/BAP/BAB/GinkgoBulletin.html

15. Veit M. Pflanzliche Arzneidrogen und einfache Arzneizubereitungen. Sticher O, Heilmann J, Zündorf I, editors. Stuttgart: Wissenschaftliche Verlagsgesellschaft; 2015; pp. 141-70.

16. European Pharmacopoeia 9th Edition. Strasbourg: Council of Europe, published 2016, valid from 1 January 2017.

17. European Medicines Agency. EMA/HMPC/201116/2005 Rev. 2, 2011. Guideline on quality of herbal medicinal products/traditional herbal medicinal products. London: 31 March 2011.

18. Sticher O. Phenolische Verbindungen. Sticher O, Heilmann J, Zündorf I, editors. Stuttgart: Wissenschaftliche Verlagsgesellschaft; 2015; pp. 741-858.

19. Rotblatt MD. Herbal medicine: a practical guide to safety and quality assurance. West $\mathrm{J}$ Med. 1999;171(3):172-5.

20. van Beek TA, Montoro P. Chemical analysis and quality control of Ginkgo biloba leaves, extracts, and phytopharmaceuticals. J Chromatogr A. 2009;1216(11):2002-32.

21. Stockler S, Plecko B, Gospe Jr SM, Coulter-Mackie M, Connolly M, van Karnebeek C, et al. Pyridoxine dependent epilepsy and antiquitin deficiency: clinical and molecular characteristics and recommendations for diagnosis, treatment and follow-up. Mol Genet Metab. 2011;104(1-2):48-60.

22. Birks J, Grimley Evans J. Ginkgo biloba for cognitive impairment and dementia. Cochrane Database Syst Rev. 2009;(1):CD003120.

23. European Medicines Agency. EMA/HMPC/321095/201228. Assessment report on Ginkgo biloba L., folium. London: 28. January 2014.

24. Herrschaft H, Nacu A, Likhachev S, Sholomov I, Hoerr R, Schlaefke S. Ginkgo biloba extract EGb 761 ® in dementia with neuropsychiatric features: A randomised, placebo-controlled trial to confirm the efficacy and safety of a daily dose of $240 \mathrm{mg}$. J Psychiatr Res. 2012;46(6):716-23.

25. Ihl R, Tribanek M, Bachinskaya N. Baseline neuropsychiatric symptoms are effect modifiers in Ginkgo biloba extract (EGb 761®) treatment of dementia with neuropsychiatric features. Retrospective data analyses of a randomized controlled trial. J Neurol Sci. 2010;299(1-2):184-7.

26. Ihl R, Bachinskaya N, Korczyn AD, Vakhapova V, Tribanek M, Hoerr R, Napryeyenko O. Efficacy and safety of a once-daily formulation of Ginkgo biloba extract EGb 761 in dementia with neuropsychiatric features: A randomized controlled trial. Int J Geriatr Psychiatry. 2011;26(11):1186-94.

27. Ihl R, Tribanek M, Bachinskaya N. Efficacy and tolerability of a once daily formulation of Ginkgo biloba extract EGb $761 \circledR$ in Alzheimer's disease and vascular dementia: Results from a randomised controlled trial. Pharmacopsychiatry. 2012;45(2):41-6. 
28. Napryeyenko O, Borzenko I. Ginkgo biloba special extract in dementia with neuropsychiatric features: A randomised, placebo-controlled, double-blind clinical trial. Arzneim -Forsch Drug Res. 2007;57(1):4-11.

29. Napryeyenko O, Sonnik G, Tartakovsky I. Efficacy and tolerability of Ginkgo biloba extract EGb $761 \circledR$ by type of dementia: Analyses of a randomised controlled trial. J Neurol Sci. 2009;283(12):224-9.

30. Kanowski S, Herrmann WM, Stephan K, Wierich W, Hörr R. Proof of efficacy of the Ginkgo biloba special extract EGb 761 in outpatients suffering from mild to moderate primary degenerative dementia of the Alzheimer type or multi-infarct dementia. Pharmacopsychiatry. 1996;29(2):47-56.

31. Kanowski S, Hoerr R. Ginkgo biloba extract EGb 761® in dementia: Intent-to-treat analyses of a 24-week, multi-center, double-blind, placebo-controlled, randomized trial. Pharmacopsychiatry. 2003;36(6):297-303.

32. Le Bars PL, Kieser M, Itil KZ. A 26-week analysis of a double-blind, placebo-controlled trial of the Ginkgo biloba extract EGb 761® in dementia. Dementia Geriatr Cogn Disord. 2000;11(4):230-7.

33. Yancheva S, Ihl R, Nikolova G, Panayotov P, Schlaefke S, Hoerr R. Ginkgo biloba extract EGb 761, donepezil or both combined in the treatment of Alzheimer's disease with neuropsychiatric features: A randomised, double-blind, exploratory trial. Aging Ment Health. 2009;13(2):183-90.

34. Rang HP, Ritter JM, Flower RJ, Henderson G. Rang \& Dale's Pharmacology. 8th ed. Edinburgh: Elsevier Churchill Livingstone; 2016. 489-90 p.

35. van Dongen MCJM, van Rossum E, Kessels AGH, Sielhorst HJG, Knipschild PG. The efficacy of ginkgo for elderly people with dementia and age-associated memory impairment: New results of a randomized clinical trial. J Am Geriatr Soc. 2000;48(10):1183-94.

36. McCarney R, Fisher P, Iliffe S, van Haselen R, Griffin M, van der Meulen J, Warner J. Ginkgo biloba for mild to moderate dementia in a community setting: A pragmatic, randomised, parallel-group, double-blind, placebo-controlled trial. Int J Geriatr Psychiatry. 2008;23(12):1222-30.

37. Schneider LS, DeKosky ST, Farlow MR, Tariot PN, Hoerr R, Kieser M. A randomized, doubleblind, placebo-controlled trial of two doses of Ginkgo biloba extract in dementia of the Alzheimer's type. Curr Alzheimer Res. 2005;2(5):541-51.

38. Institut für Qualität und Wirtschaftlichkeit im Gesundheitswesen (IQWIG) A05-19B. Ginkgohaltige Präparate bei Alzheimer Demenz. Köln: 29. September 2008.

39. Weinmann S, Roll S, Schwarzbach C, Vauth C, Willich SN. Effects of Ginkgo biloba in dementia: systematic review and meta-analysis. BMC Geriatr. 2010;10:14.

40. Blumenthal M, Busse WR, Goldberg A, Gruenwald J, Hall T, Klein S, et al. The Complete German Commission E Monographs. Austin: American Botanical Council; 1998. pp. 136-8.

41. World Health Organization (WHO). Folium Ginkgo. WHO Monographs on Selected Medicinal Plants, Vol. 1. Geneva: 1999. pp. 154-67.

42. European Scientific Cooperative On Phytotherapy (ESCOP). Ginkgo folium. ESCOP Monographs, 2nd ed. Exeter: 2003. pp. 178-210.

43. DeKosky ST, Williamson JD, Fitzpatrick AL, Kronmal RA, Ives DG, Saxton JA, et al. Ginkgo biloba for prevention of dementia: A randomized controlled trial. J Am Med Assoc. 2008;300(19):2253-62. 
44. Vellas B, Coley N, Ousset PJ, Berrut G, Dartigues JF, Dubois B, et al. Long-term use of standardised Ginkgo biloba extract for the prevention of Alzheimer's disease (GuidAge): A randomised placebocontrolled trial. Lancet Neurol. 2012;11(10):851-9.

45. Stefanova E, Pavlović A, Semnic M, Janjić V, Petrović M, Milošević V, et al. Vodič za Alchajmerovu bolest. Belgrade: June 2013.

46. Snitz BE, O'Meara ES, Carlson MC, Arnold AM, Ives DG, Rapp SR, et al. Ginkgo biloba for preventing cognitive decline in older adults a randomized trial. $\mathrm{J}$ Am Med Assoc. 2009;302(24):2663-70.

47. Deutsche Gesellschaft für Psychiatrie und Psychotherapie, Psychosomatik und Nervenheilkunde (DGPPN), Deutsche Gesellschaft für Neurologie (DGN). S3-Leitlinie "Demenzen": Langversion. January 2016.

48. Deutsche Gesellschaft für Neurologie (DGN). Leitlinien für Diagnostik und Therapie in der Neurologie. Vaskuläre Demenzen. 2017.

49. Savaskan E, Mueller H, Hoerr R, von Gunten A, Gauthier S. Treatment effects of Ginkgo biloba extract $\mathrm{EGb} 761{ }^{\circledR}$ on the spectrum of behavioral and psychological symptoms of dementia: metaanalysis of randomized controlled trials. Int Psychogeriatr. 2018;30(3):285-93.

50. Nikolova G, Yancheva S, Raychev I, Hoerr R. PLAGIN Study Group Ginkgo biloba extract in dementia: a 22-week randomised, placebo-controlled, double-blind trial. Bulgarian Neurol. 2013;14:139-43.

51. Spiegel R, Kalla R, Mantokoudis G, Maire R, Mueller H, Hoerr R, Ihl R. Ginkgo biloba extract EGb $761{ }^{\circledR}$ alleviates neurosensory symptoms in patients with dementia: a meta-analysis of treatment effects on tinnitus and dizziness in randomized, placebo-controlled trials. Clin Interv Aging. 2018;13:1121-7.

52. Gessner B, Voelp A, Klasser M. Study of the long-term action of a Ginkgo biloba extract on vigilance and mental performance as determined by means of quantitative pharmaco-EEG and psychometric measurements. Arzneimittelforschung. 1985;35(9):1459-65.

53. Santos RF, Galduróz JC, Barbieri A, Castiglioni ML, Ytaya LY, Bueno OF. Cognitive performance, SPECT, and blood viscosity in elderly non-demented people using Ginkgo biloba. Pharmacopsychiatry. 2003;36(4):127-33.

54. Guinot P, Caffrey E, Lambe R, Darragh A. Tanakan inhibits platelet-activating-factor-induced platelet aggregation in healthy male volunteers. Haemostasis. 1989;19(4):219-23.

55. Mehlsen J, Drabaek H, Wiinberg N, Winther K. Effects of a Ginkgo biloba extract on forearm haemodynamics in healthy volunteers. Clin Physiol Funct Imaging. 2002;22(6):375-8.

56. Oberpichler H, Beck T, Abdel-Rahman MM, Bielenberg GW, Krieglstein J. Effects of Ginkgo biloba constituents related to protection against brain damage caused by hypoxia. Pharmacol Res Commun. 1988;20(5):349-68.

57. Ahlemeyer B, Krieglstein J. Pharmacological studies supporting the therapeutic use of Ginkgo biloba extract for Alzheimer's disease. Pharmacopsychiatry. 2003;36 Suppl 1:S8-S14. 
58. Janssens D, Michiels C, Delaive E, Eliaers F, Drieu K, Remacle J. Protection of hypoxia-induced ATP decrease in endothelial cells by Ginkgo biloba extract and bilobalide. Biochem Pharmacol. 1995;50(7):991-9.

59. Janssens D, Delaive E, Remacle J, Michiels C. Protection by bilobalide of the ischaemia-induced alterations of the mitochondrial respiratory activity. Fundam Clin Pharmacol. 2000;14(3):193-201.

60. Braquet PG, Spinnewyn B, Braquet M, Bourgain RH, Taylor JE, Etienne A, Drieu K. BN 52021 and related compounds: A new series of highly specific PAF-acether receptor antagonists isolated from Ginkgo biloba L. Blood \& Vessel. 1985;16(6):558-72.

61. Akiba S, Kawauchi T, Oka T, Hashizume T, Sato T. Inhibitory effect of the leaf extract of Ginkgo biloba L. on oxidative stress-induced platelet aggregation. Biochem Mol Biol Int. 1998;46(6):1243-8.

62. Koch E. Inhibition of platelet activating factor (PAF)-induced aggregation of human thrombocytes by ginkgolides: considerations on possible bleeding complications after oral intake of Ginkgo biloba extracts. Phytomedicine. 2005;12(1-2):10-6.

63. Koltermann A. Influence of Ginkgo biloba extract EGb 761® on signaling pathways in endothelial cells [dissertation]. [Munich (DE)]: Ludwig-Maximilians-Universität; 2007. 155 p.

64. Shi C, Liu J, Wu F, Yew DT. Ginkgo biloba extract in Alzheimer's disease: from action mechanisms to medical practice. Int J Mol Sci. 2010;11(1):107-23.

65. Du ZY, Li XY. Effects of ginkgolides on interleukin-1, tumor necrosis factor-alpha and nitric oxide production by rat microglia stimulated with lipopolysaccharides in vitro. Arzneimittelforschung. 1998;48(12):1126-30.

66. Taylor JE. Binding of neuromediators to their receptors in rat brain. Effect of chronic administration of Ginkgo biloba extract. Fünfgeld EW, editor. Berlin, Heidelberg: Springer-Verlag; 1988; pp. 103-8.

67. Kehr J, Yoshitake S, Ijiri S, Koch E, Nöldner M, Yoshitake T. Ginkgo biloba leaf extract (EGb $\left.761{ }^{\circledR}\right)$ and its specific acylated flavonol constituents increase dopamine and acetylcholine levels in the rat medial prefrontal cortex: possible implications for the cognitive enhancing properties of EGb 761®. Int Psychogeriatr. 2012;24 Suppl 1:S25-S34.

68. Granger AS. Ginkgo biloba precipitating epileptic seizures. Age Ageing. 2001;30(6):523-5.

69. Härtter S, Sennewald R, Nehmiz G, Reilly P. Oral bioavailability of dabigatran etexilate (Pradaxa $\left.{ }^{\circledR}\right)$ after co-medication with verapamil in healthy subjects. Br J Clin Pharmacol. 2013;75(4):1053-62.

70. Fan L, Mao XQ, Tao GY, Wang G, Jiang F, Chen Y, et al. Effect of Schisandra chinensis extract and Ginkgo biloba extract on the pharmacokinetics of talinolol in healthy volunteers. Xenobiotica. 2009;39(3):249-54.

71. Fan L, Tao GY, Wang G, Chen Y, Zhang W, He YJ, et al. Effects of Ginkgo biloba extract ingestion on the pharmacokinetics of talinolol in healthy Chinese volunteers. Ann Pharmacother. 2009;43(5):944-9.

72. Yoshioka M, Ohnishi N, Koishi T, Obata Y, Nakagawa M, Matsumoto T, et al. Studies on interactions between functional foods or dietary supplements and medicines. IV. Effects of Ginkgo biloba leaf extract on the pharmacokinetics and pharmacodynamics of nifedipine in healthy volunteers. Biol Pharm Bull. 2004;27(12):2006-9. 
73. Naccarato M, Yoong D, Gough K. A potential drug-herbal interaction between Ginkgo biloba and efavirenz. J Int Assoc Physicians AIDS Care (Chic). 2012;11(2):98-100.

74. Elmazoudy RH, Attia AA. Efficacy of Ginkgo biloba on vaginal estrous and ovarian histological alterations for evaluating anti-implantation and abortifacient potentials in albino female mice. Birth Defects Res B Dev Reprod Toxicol. 2012;95(6):444-59.

75. DeFeudis FV. Ginkgo biloba extract (EGb 761): from chemistry to the clinic. Wiesbaden: Ullstein Medical; 1998.

76. Shiao NH, Chan WH. Injury effects of ginkgolide B on maturation of mouse oocytes, fertilization, and fetal development in vitro and in vivo. Toxicol Lett. 2009;188(1):63-9.

77. Chan WH. Ginkgolides induce apoptosis and decrease cell numbers in mouse blastocysts. Biochem Biophys Res Commun. 2005;338(2):1263-7.

78. Baron-Ruppert G, Luepke NP. Evidence for toxic effects of alkylphenols from Ginkgo biloba in the hen's egg test (HET). Phytomedicine. 2001;8(2):133-8.

79. Gauthier S, Schlaefke S. Efficacy and tolerability of Ginkgo biloba extract EGb 761® in dementia: a systematic review and meta-analysis of randomized placebo-controlled trials. Clin Interv Aging. 2014;9:2065-77.

80. Hashiguchi M, Ohta Y, Shimizu M, Maruyama J, Mochizuki M. Meta-analysis of the efficacy and safety of Ginkgo biloba extract for the treatment of dementia. J Pharm Health Care Sci. 2015;1:14.

81. Tan MS, Yu JT, Tan CC, Wang HF, Meng XF, Wang C, et al. Efficacy and adverse effects of Ginkgo biloba for cognitive impairment and dementia: a systematic review and meta-analysis. J Alzheimers Dis. 2015;43(2):589-603.

82. Joseph N, Abhishai B, Thouseef MF, Abna A, Juneja I. A multicenter review of epidemiology and management of varicose veins for national guidance. Ann Med Surg (Lond). 2016;8:21-7.

83. Rha SW, Choi SH, Kim DI, Jeon DW, Lee JH, Hong KS, et al. Medical resource consumption and quality of life in peripheral arterial disease in Korea: PAD outcomes (PADO) research. Korean Circ J. 2018;48(9):813-25.

84. European Medicines Agency. EMA/HMPC/322570/2011 Rev. 7. Uptake of the traditional use registration scheme and implementation of the provisions of Directive 2004/24/EC in EU Member States. Status: 31 December 2016. London: 18 April 2017.

85. Medicines and Medical Devices Agency of Serbia [Internet]. Search for human medicines [cited 2020 April 27]. Available from: https:/www.alims.gov.rs/eng/medicinal-products/search-forhuman-medicines/ 


\title{
Biljni lekovi na bazi ekstrakta lista ginka kod blage demencije
}

\author{
Silvana Petrović ${ }^{*}$ Ljuboš Ušjak
}

Univerzitet u Beogradu - Farmaceutski fakultet, Katedra za farmakognoziju, Vojvode Stepe 450, 11221 Beograd, Srbija

Autor za korespondenciju: silvana.petrovic@pharmacy.bg.ac.rs

\section{Kratak sadržaj}

Prema aktuelnoj monografiji EU Komiteta za biljne lekovite proizvode Evropske agencije za lekove (EMA/HMPC) za list ginka, Ginkgonis folium (Ginkgo biloba, Ginkgoaceae), biljni lekovi na bazi suvog prečišćenog kvantifikovanog ekstrakta lista ginka koriste se za ublažavanje (sa starošću povezanog) kognitivnog oštećenja i za poboljšanje kvaliteta života kod blage demencije. U kliničkim studijama je pokazana efikasnost hronične primene ekstrakta prevashodno kod pacijenata starosti preko 50 godina. Precizan mehanizam delovanja nije poznat. Prema Ph. Eur., ekstrakt treba da sadrži 22,0-27,0\% flavonoida, 2,8-3,4\% ginkolida A, B i C i 2,6-3,2\% bilobalida, koji spadaju u aktivne sastojke, kao i najviše 5 ppm ginkolnih kiselina koje su potencijalni alergeni. Ove biljne lekove karakterišu odgovarajući režim doziranja i dužina primene, kontraindikacije, posebna upozorenja i mere opreza, interakcije i moguće neželjene reakcije.

Ključne reči: Ginkgo biloba; ekstrakt lista; blaga demencija; biljni lekovi; efikasnost i bezbednost 